\title{
ANALISIS PENERAPAN MANAJEMEN OPERASIONAL (DESAIN PRODUK DAN RANTAI PASOKAN) PADA UKM ROTAN KELOMPOK PAHARI PALANGKA RAYA
}

\author{
Sri Rohaetin ${ }^{1)}$, Intan Norrahmi ${ }^{2)}$ \\ Program Studi Pendidikan Ekonomi, \\ Fakultas Keguruan dan Ilmu Pendidikan Universitas Palangka Raya \\ sri.rohaetin@edu.upr.ac.id
}

\begin{abstract}
The method used in this research is descriptive method which is a method that aims to describe a problem clearly. The type of data used is primary data and secondary data. Data collection techniques consist of observation, interview and documentation. Data analysis was performed using qualitative data analysis techniques consisting of three stages of activities carried out sequentially namely reducing data, presenting data, and drawing conclusions. The results of this study indicate that the appropriate product design operational management to increase the sales results of the Pahari Palangka Raya Group Rattan UKM products is by applying eight aspects of product design (shape, features, performance, suitability, durability, reliability, style, and ease of repair) with priority on marketed products and prices. And in the proper supply chain operational management to increase the production output of the Pahari Palangkaraya Rattan Group UKM by implementing a strategy.
\end{abstract}

Keywords: Management of Product Design, Supply Chain Operations

\begin{abstract}
Abstrak
Metode yang digunakan dalam penelitian ini adalah metode deskriptif yaitu suatu metode yang bertujuan untuk menggambarkan suatu masalah secara jelas. Jenis data yang digunakan adalah data primer dan data sekunder. Teknik pengumpulan data terdiri dari observasi, wawancara dan dokumentasi. Analisis data dilakukan dengan menggunakan teknik analisis data kualitatif yang terdiri dari tiga tahapan kegiatan yang dilakukan secara berurutan yaitu mereduksi data, penyajian data, dan menarik kesimpulan. Hasil penelitian ini menunjukan bahwa Manajemen operasional desain produk yang tepat untuk meningkatkan hasil penjualan produk UKM Rotan Kelompok Pahari Palangka Raya yaitu dengan menerapkan delapan aspek desain produk (bentuk, fitur, kinerja, kesesuaian, ketahanan, kehandalan, gaya, dan kemudahan perbaikan) dengan prioritas pada produk dan harga yang dipasarkan. Dan dalam manajemen operasional rantai pasokan yang tepat untuk meningkatkan hasil produksi UKM Rotan Kelompok Pahari Palangka Raya yaitu dengan menerapkan strategi.
\end{abstract}

Kata Kunci: Manajemen Operasional Desain Produk, Rantai Pasokan 


\section{PENDAHULUAN}

Persaingan zaman globalisasi semakin ketat. Pengaruh globalisasi dalam bidang teknologi informasi mengakibatkan dunia menjadi semakin terbuka, cepat, dan bersifat universal, menyebabnya peningkatan akses informasi menjadi lebih mudah. Seperti halnya dampak globalisasi di bidang teknologi yang memacu diciptanya mesinmesin canggih yang dapat membantu pekerjaan manusia. Dilihat dari dampak globalisasi dibidang tersebut, globalisasi terbukti telah memberikan pengaruh besar diberbagai bidang kehidupan, termasuk bidang ekonomi. Salah satu dampak globalisasi di bidang ekonomi yang paling menonjol adalah bebasnya pasar internasional. Kebebasan pasar internasional ini membuka peluang kerja yang semakin besar, meningkatkan sumber pendapatan suatu negara. Dampak lainnya ialah dengan dengan terciptanya bisnis E-commerce. Bisnis E-commerce merupakan bisnis berbasis internet. Manfaat dari adanya bisnis E-commerce adalah kemudahan dalam memperoleh produk, menghemat waktu dan biaya, dapat diakses secara fleksibel, dan kemudahan dalam sistem pembayaran. Sekarang tidak perlu modal banyak untuk mendapatkan informasi yang diperlukan. Cukup pencarian dengan kata kunci maka munculah informasi yang kita perlukan.

Manajer yang sukses dalam merancang dan menyediakan barang dan jasa di seluruh dunia adalah manajer yang memahami manajemen operasional. Manajemen operasional merupakan salah satu faktor terpenting bagi kelangsungan sebuah perusahaan. Karena dengan adanya manajemen operasional pembagian kinerja dan proses kinerja perusahaan dapat berjalan dengan baik. Sehingga mendukung pencapaian visi, misi, dan tujuan perusahaan. Manajemen operasional sebagai divisi dengan jumlah penggunaan dana terbesar memerlukan perhatian karena dari sini dapat diketahui bagaimana produk tersebut di produksi. Mulai dari input, proses, output serta segala keputusan yang harus diambil dalam manajemen operasional. Menurut Haizer dan Rander (2016: 6) terdapat sepuluh keputusan strategis dalam manajemen operasional yaitu, desain produk, manajemen mutu, tata letak, lokasi, desain proses atau kapasitas, rancangan kerja sumber daya manusia, manajemen rantai pasokan, persediaan, penjadwalan, dan pemeliharaan.

Sekali barang dan jasa dihasilkan, kemudian dijual menjadi uang yang selanjutnya digunakan untuk membelikan sumber daya lagi, sehingga proses produksi dapat terus berlanjut. Laku tidaknya produk akan semakin ditentukan oleh kejelian, keterampilan, dan desain dalam memenuhi keinginan konsumen. Masyarakat menginginkan produk yang berkualitas dengan harga murah, sehingga produsen dituntut untuk mengasilkan barang sesuai harapan konsumen. Maka peran manajemen operasional dalam menghadapi era globalisasi adalah efektif dan efisien dalam produksi, kualitas fisik dan desain meningkat, menciptakan waktu tunggu yang relatif singkat, dan kapasitas produksi mampu memenuhi kebutuhan. Partisipasi pelanggan dapat digunakan untuk menghemat tenaga kerja. Pelanggan tidak hanya sebagai pemakai tetapi juga berperan dalam menghasilkan barang atau jasa.

Di Indonesia usaha kecil dan menengah (UKM) merupakan tulang punggung perekonomian negara. Dengan adanya UKM terbukti mampu mendorong roda perekonomian bangsa untuk berputar dan mengurangi jumlah pengangguran yang ada, dengan memproduksi sebuah produk sendiri, UKM melakukan produksi dari awal produksi hingga pemasaran secara mandiri.

Meski para pelaku UKM memiliki beberapa keterbatasan namun pada 
kenyataannya mereka mampu bersaing dengan perusahaan besar. Bahkan pada saat kondisi perekonomian memburuk para pelaku UKM ini tetap mampu untuk bertahan. Fakta ini menunjukan kekuatan dari para pelaku UKM tidak kalah dengan pelaku perusahaan yang bertaraf besar, dan tidak dipungkiri juga UKM ini muncul karena mereka telah menerapkan visi kewirausahaan sehingga mereka mampu membawa perusahaannya tumbuh dan berkembang serta memperoleh peningkatan profit.

Dalam UU No. 20 Tahun 2008 menjelaskan pengertian tentang usaha kecil dan usaha menengah sebagai berikut: Usaha kecil adalah usaha ekonomi produktif yang berdiri sendiri, yang dilakukan oleh perorangan atau badan usaha yang bukan merupakan anak perusahaan atau bukan cabang perusahaan yang dimiliki, dikuasai atau menjadi bagian baik langsung maupun tidak langsung dari usaha menengah atau usaha besar yang memenuhi kriteria usaha kecil sebagaimana dimaksud dalam undangundang ini, memiliki kekayaan bersih paling banyak Rp. 50.000.000,00 (lima puluh juta rupiah) sampai dengan paling banyak $\mathrm{Rp}$. 500.000.000,00 (lima ratus juta rupiah) tidak termasuk tanah dan bangunan tempat usaha; atau memiliki penjualan tahunan lebih dari Rp. 300.000.000,00 (tiga ratus juta rupiah) sampai dengan paling banyak Rp. 2.500.000.000,00 (dua milyar lima ratus juta rupiah).

Usaha menengah adalah usaha ekonomi produktif yang berdiri sendiri, yang dilakukan oleh orang perorangan atau badan usaha yang bukan merupakan anak perusahaan atau bukan cabang perusahaan yang dimiliki, dikuasai atau menjadi bagian baik langsung maupun tidak langsung dengan usaha kecil atau usaha besar dengan jumlah kekayaan bersih atau penghasilan tahunan sebagaimana diatur dalam undang- undang, memiliki kekayaan bersih lebih dari Rp. 500.000.000,00 (lima ratus juta rupiah) sampai dengan paling banyak Rp. 10.000.000.000,00 (sepuluh milyar rupiah) tidak termasuk tanah dan bangunan tempat usaha; atau memiliki hasil penjualan tahunan lebih dari Rp. 2.500.000.000,00 (dua milyar lima ratus juta rupiah) sampai dengan paling banyak Rp. 50.000.000.000,00 (lima puluh milyar rupiah).

Di kota Palangka Raya dewasa ini telah berdiri 13 (tiga belas) usaha kecil dan menengah (UKM) kerajinan rotan, salah satu diantaranya yaitu UKM Rotan Kelompok Pahari Palangka Raya. Dimana usaha yang dijalankan merupakan olahan dari bahan baku rotan setengah jadi menjadi produk jadi atau siap pakai yang memiliki nilai jual yang lebih tinggi. Usaha yang bergerak di bidang pengolahan rotan dari bahan baku setengah jadi hingga produk jadi atau siap pakai yang masih terbatas pada industri rumah tangga (home industry) seperti kerajinan rotan, tikar, tas, topi, dan lawung. Dengan melimpahnya ketersediaan bahan baku rotan di Kalimantan Tengah merupakan salah satu alasan bagi UKM Rotan Kelompok Pahari Palangka Raya menggunakan bahan baku rotan setengah jadi menjadi produk jadi atau siap pakai. Selain itu, dalam rangka melestarikan budaya dan merubah pandangan atau pola pikir masyarakat bahwa rotan memiliki nilai ekonomi yang jauh lebih tinggi, baik pemasaran secara lokal maupun internasional. Rotan merupakan salah satu sumber daya alam yang harus dilestarikan dan dimanfaatkan secara maksimal. Rotan pada awalnya hanya digunakan sebagai bahan tali pengikat dan bahan pembuatan alat penangkap ikan. Namun dengan adanya perubahan sikap, minat pelaku, dan perkembangan ekonomi, kegunaan rotan telah berkembang untuk berbagai keperluan. Berikut adalah data pesaing UKM Rotan Kelompok Pahari Palangka Raya: 
Tabel 1. Data Pesaing UKM Rotan Kelompok Pahari Palangka Raya

\begin{tabular}{|c|c|c|c|}
\hline NO & $\begin{array}{r}\text { NAMA } \\
\text { USAHA }\end{array}$ & $\begin{array}{c}\text { ALAMAT USAHA } \\
\text { / NO. HP }\end{array}$ & $\begin{array}{c}\text { JENIS } \\
\text { USAHA }\end{array}$ \\
\hline 1 & Pahias & $\begin{array}{c}\text { Jl. Raden Patah No. } \\
\text { 40 Palangka Raya } \\
\text { Hp. } 081383295558\end{array}$ & $\begin{array}{l}\text { Kerajinan } \\
\text { rotan, tas, } \\
\text { sepatu, } \\
\text { tikar, topi, } \\
\text { gelang, dll }\end{array}$ \\
\hline 2 & Jawet Weni & $\begin{array}{c}\text { Jl. G. Obos VII Gg. } \\
\text { Rabakoy Jaya } \\
\text { Palangka Raya } \\
\text { Hp. } 081349077198\end{array}$ & $\begin{array}{l}\text { Kerajinan } \\
\text { rotan, tas, } \\
\text { tikar, } \\
\text { lawung, } \\
\text { hiasan } \\
\text { dinding, dll }\end{array}$ \\
\hline 3 & Jawet Niang & $\begin{array}{l}\text { Jl. RTA Milono } \\
\text { Km. } 8 \text { Perum } \\
\text { Kereng Indah } \\
\text { Permai II No. } 26 \\
\text { Palangka Raya } \\
\text { Hp. } 085332721461\end{array}$ & $\begin{array}{l}\text { Kerajinan } \\
\text { rotan, tas, } \\
\text { lawung, } \\
\text { gelang, } \\
\text { tikar, dll }\end{array}$ \\
\hline 4 & Grage Rotan & $\begin{array}{c}\text { Jl. G. Obos } \\
\text { Seberang Kantor } \\
\text { BPTP Palangka } \\
\text { Raya } \\
\text { Hp. } 081251716636\end{array}$ & $\begin{array}{c}\text { Meubel } \\
\text { rotan, } \\
\text { keranjang, } \\
\text { tudung saji, } \\
\text { pas bunga, } \\
\text { dll }\end{array}$ \\
\hline 5 & Marina Rotan & $\begin{array}{c}\text { J1. Tjilik Riwut KM. } \\
5 \text { Palangka Raya } \\
\text { Hp. } 08115203458\end{array}$ & $\begin{array}{l}\text { Meubel } \\
\text { rotan }\end{array}$ \\
\hline 6 & Jawet Rawi & $\begin{array}{l}\text { Jl. Kapten Piere } \\
\text { Tandean No. } 3 \\
\text { Palangka Raya } \\
\text { Hp. } 08525007183\end{array}$ & $\begin{array}{l}\text { Kerajinan } \\
\text { rotan, tas, } \\
\text { topi, } \\
\text { lawung, dll }\end{array}$ \\
\hline 7 & GE Ethnic & $\begin{array}{c}\text { Jl. Sangga Buana I } \\
\text { No. } 034 \text { Palangka } \\
\text { Raya } \\
\text { Hp. } 0811525282\end{array}$ & $\begin{array}{l}\text { Kerajinan } \\
\text { rotan, } \\
\text { lawung, dll }\end{array}$ \\
\hline 8 & AAZR & $\begin{array}{l}\text { Jl. Kutilang Perum } \\
\text { Kutilang Asri II No. } \\
7 \text { Palangka Raya } \\
\text { Hp. } 082153661010\end{array}$ & $\begin{array}{c}\text { Kerajinan } \\
\text { tas, lawung, } \\
\text { tikar, dll }\end{array}$ \\
\hline 9 & $\begin{array}{c}\text { Jawet Bawi } \\
\text { Rawi }\end{array}$ & $\begin{array}{c}\text { Jl. Rajawali IV } \\
\text { Palangka Raya } \\
\text { Hp. } 085252810829\end{array}$ & $\begin{array}{l}\text { Kerajinan } \\
\text { rotan }\end{array}$ \\
\hline 10 & Jawet Rawi & $\begin{array}{l}\text { Jl. Tandean No. } 3 \\
\text { Palangka Raya } \\
\text { Hp. } 085250071835\end{array}$ & $\begin{array}{l}\text { Kerajinan } \\
\text { rotan }\end{array}$ \\
\hline 11 & Duta Dare & $\begin{array}{l}\text { J1. Menteng X No. } 3 \\
\text { Palangka Ray } \\
\text { Hp. } 082157044156\end{array}$ & $\begin{array}{l}\text { Kerajinan } \\
\text { rotan }\end{array}$ \\
\hline 12 & Jawet Durian & $\begin{array}{c}\text { Jl. Samsudin Aman } \\
\text { Palangka Raya } \\
\text { Hp. } 082256836043\end{array}$ & $\begin{array}{l}\text { Kerajinan } \\
\text { rotan }\end{array}$ \\
\hline
\end{tabular}

Sumber: Binaan PLUT KUMKM Provinsi Kalimantan Tengah, Dinas Koperasi dan UKM Provinsi Kalimantan Tengah Tahun 2019

Permasalahan yang muncul dari produk hasil olahan UKM Rotan Kelompok Pahari Palangka Raya yaitu tentang desain produk yang menjadi faktor penting bagi konsumen untuk membeli suatu produk. Sangat banyak desain kerajinan rotan yang ditawarkan oleh penjual kepada konsumen. Setiap konsumen memiliki selera berbeda dalam memilih desain kerajinan rotan yang ingin dibelinya. Dengan kondisi persaingan pasar yang semakin ketat, menuntut pelaku UKM Rotan Kelompok Pahari Palangka Raya untuk meningkatkan desain produk kerajinan rotan agar dapat bersaing dengan produk kerajinan rotan UKM lainnya.

Menurut Kotler dan Keller (2009:10) "Desain produk adalah totalitas fitur yang mempengaruhi tampilan, rasa, dan fungsi produk berdasarkan kebutuhan pelanggan". Desain produk yang unik, ukuran yang bermacam-macam, warna dan bentuk akan semakin mempengaruhi konsumen dalam menentukan pilihan produk. Namun karena dituntut dengan kebutuhan fashion yang terus mengalami perubahan membuat sebagian orang hanya memikirkan tentang model (bentuk), tetapi banyak yang melupakan sisi kualitas dari produk tersebut.

Selain itu masalah yang muncul adalah penerapan strategi rantai pasokan yang memegang peranan penting dalam peningkatan usaha kerajinan rotan dan perlu dilakukan dengan baik. Proses produksi dan distribusi kerajinan rotan yang berkualitas, murah dan cepat. UKM rotan tentunya membutuhkan pihak lain seperti, pemasok, distributor, retailer, hingga konsumen. Sehingga muncul sebuah konsep rantai pasokan. Rantai pasokan merupakan proses penciptaan nilai tambah dan jasa yang berfokus pada efisiensi dari persediaan, arus kas dan aliran informasi. Kegiatan rantai pasokan ini tidak lepas dari keberadaan mata rantai atau lembaga pemasaran yang terkait didalamnya. Kegiatan yang dilakukan dapat berupa pengeluaran barang, pengolahan barang maupun peraturan-peraturan lainnya baik itu peraturan harga dan komunikasi. 
Kegiatan tersebut dilakukan agar keuntungan dapat diraih oleh mata rantai yang terlibat serta tujuan yang diinginkan oleh masingmasing mata rantai tercapai. Dampak dari kegiatan rantai pasokan tersebut adalah adanya penambahan nilai dan perubahan produk akibat adanya proses pengolahan dalam rantai pasokan yang diperlukan untuk memenuhi kebutuhan konsumen. Menurut Ma'arif dan Tanjung (2003: 357), terdapat lima strategi yang dapat dipilih perusahaan untuk melakukan pembelian kepada supplier yaitu banyak pemasok, sedikit pemasok, integrasi vertikal, jaringan keiretsu, dan perusahaan maya.

Dalam hal inilah perusahaan yang bergerak di bidang pengolahan rotan menjadi produk jadi atau siap pakai perlu memperhatikan manajemen operasional desain produk dan rantai pasokan agar tidak kalah saing dengan perusahaan lain yang juga memasarkan produk yang sama.

Kegiatan manajemen operasional mencakup beberapa keputusan, beberapa halnya yaitu desain produk dan rantai pasokan yang sesuai dengan apa yang diinginkan konsumen, kemudian merencanakan dan mengembangkan sebuah produk atau jasa yang memenuhi keinginan tersebut dan memutuskan secara baik untuk menentukan harga, mempromosikan, dan mendistribusikan produk. Secara lebih formal manajemen operasional adalah kegiatan yang berhubungan dengan perencanaan, pengkoordinasian, penggerakan, dan pengendalian aktivitas organisasi atau perusahaan bisnis atau jasa yang berhubungan dengan proses pengolahan masukan menjadi keluaran dengan nilai tambah yang lebih besar.

Manajemen operasional sangat erat kaitannya dengan tiga keputusan dan aktivitas utama, yaitu keputusan desain, transformasi, dan perbaikan terus-menerus atas sistem. Maka diharapkan UKM Rotan Kelompok Pahari Palangka Raya memperhatikan manajemen operasional dengan tiga keputusan dan aktivitas utama. Dimana perpaduan antara aktivitas desain dan transformasi ditargetkan untuk menciptakan nilai tambah, yaitu manfaat yang lebih besar untuk organisasi atau perusahaan. Bersamaan dengan itu, interaksi antara transformasi dan perbaikan sistem diharapkan untuk meningkatkan efisiensi proses sehingga sasaran mewujudkan nilai tambah yang lebih besar dapat dicapai. Selanjutnya, interaksi antara aktivitas desain dengan perbaikan terus-menerus diharapkan akan meningkatkan kemampuan perusahaan untuk menghasilkan keluaran yang semakin baik, semakin diterima oleh pasar, dan semakin berdaya saing. UKM yang bergerak di bidang kerajinan rotan menjadi produk jadi/siap pakai memiliki permasalahan atau kendala dalam manajemen operasional desain produk dan rantai pasokan. Adapun tujuan dari penelitian ini, 1) Untuk mengetahui penerapan manajemen operasional (desain produk dan rantai pasokan) yang dijalankan oleh UKM Rotan Kelompok Pahari Palangka Raya. 2) Untuk mengetahui faktor pendorong dan penghambat yang dihadapi UKM Rotan Kelompok Pahari Palangka Raya dalam mengembangkan usaha kerajinan rotannya.

\section{METODE PENELITIAN}

Penelitian ini menggunakan pendekatan kualitatif. Menurut Sugiyono (2013:14), metode penelitian kualitatif sering disebut metode penelitian naturalistik karena penelitiannya dilakukan pada kondisi alamiah (natural setting); disebut juga sebagai metode ethnograpi, karena pada awalnya metode ini lebih banyak digunakan untuk penelitian bidang antropologi budaya; disebut sebagai metode kualitatif karena data yang terkumpul dan analisisnya bersifat kualitatif. Penelitian ini dilakukan di UKM Rotan Kelompok Pahari Palangka Raya yang berada di jalan 
RTA. Milono Km. 10 Surung I No.48 RT. 001 RW. 001 Kecamatan Sebangau Kelurahan Sabaru, Kereng Bankirai, Kota Palangka Raya. Data primer, yang dikumpulkan berbentuk hasil wawancara yang dilakukan terhadap narasumber yang berasal dari pelaku UKM Rotan Kelompok Pahari Palangka Raya, dan data sekunder, data ini diperlukan untuk mendukung analisis dan pembahasan yang maksimal. Data sekunder juga diperlukan terkait pengungkapan fenomena sosial dalam penelitian ini. Data sekunder ini antara lain, kepustakaan (library research) serta bahan dari internet. Teknik pengumpulan data menggunakan: observasi, wawancara dan dokumentasi. Teknis analisis data merupakan langkah yang diambil setelah melakukan pengumpulan data dan disederhanakan dalam bentuk yang lebih mudah dibaca sehingga mampu memecahkan masalah penelitian. Teknik yang digunakan adalah analisis kualitatif (analisis data dilapangan) Menurut Miles dan Hubermen dalam Sugiyono (2013: 337), "Mengemukakan bahwa: aktivitas dalam analisis data kualitatif dilakukan secara interaktif dan berlangsung secara terus menerus sampai tuntas, sehingga datanya sudah jenuh". Aktivitas dalam analisis data, yaitu data redution, data display, dan conclusion drawing/verification.

Gambar 1. Langkah-Langkah Analisis Data

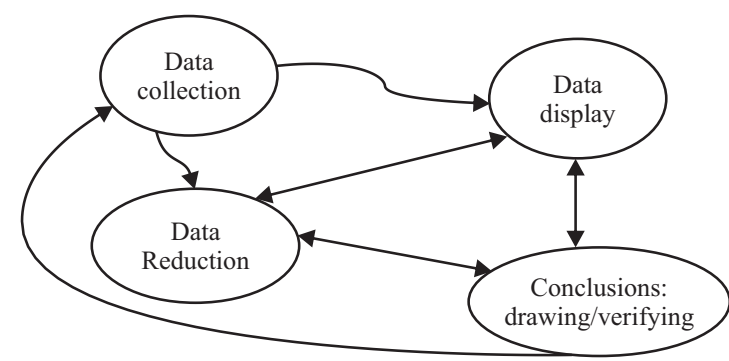

(Sumber: Sugiyono, 2013: 338)

\section{HASIL DAN PEMBAHASAN}

UKM Rotan Kelompok Pahari Palangka Raya adalah usaha perseorangan dan merupakan salah satu industri rumah tangga (home industry) di Kota Palangka Raya yang bergerak dibidang kerajinan rotan, yakni pengolahan dari bahan baku rotan setengah jadi menjadi produk jadi atau siap pakai yang didirikan pada tahun 1999 oleh Ibu Ramintje selaku pemilik usaha. Landasan hukum usaha ini didasarkan pada Surat Izin Usaha Perdagangan (SIUP) Mikro dengan Nomor: 503./225/SIUP-MIKRO/111/2011 dan telah memiliki NPWP dengan Nomor: 16.231.607.9-711.000 tertanggal 01 Juli 2011 yang beralamat di jalan RTA. Milono Km. 10 Surung I No.48 RT. 001 RW. 001 Kecamatan Sebangau, Kelurahan Sabaru, Kereng Bankirai, Kota Palangka Raya, Provinsi Kalimantan Tengah. Modal awal UKM Rotan Kelompok Pahari Palangka Raya pada awal berdiri tahun 1999 adalah sebesar Rp.3.000.000,- yang digunakan sebagai pembelian bahan baku rotan setengah jadi. Seiring perkembangannya, pada tahun 2011 UKM Rotan Kelompok Pahari Palangka Raya mendaftarkan usahanya di Usaha Perdagangan Mikro (UPK) dan telah mendapat Surat Izin Usaha Perdagangan (SIUP) Mikro maka modal yang diusulkan adalah sebesar Rp.50.000.000,-. Dimana modal yang dimaksud tidak semuanya dalam bentuk uang tunai tetapi modal yang dimaksudkan sudah termasuk peralatan dan perlengkapan seperti mesin, cat paku tembak, dan sebagainya dimana seluruh modal yang dimiliki oleh pemilik usaha dan sampai saat ini telah mengalami penambahan. UKM Rotan Kelompok Pahari Palangka Raya mendapatkan bahan baku rotan dari Barito Selatan. Selama proses produksi hingga pemasaran Ibu Ramintje dibantu oleh suami, anak, menantu dan cucu. Dalam falsafah tumbuh dan berkembangnya suatu bisnis, perusahaan melakukan kegiatan usaha yang dimanfaatkan sebesar-besarnya agar nantinya usaha dapat berkembang dan dapat bersaing di pasar. Dalam hal ini UKM Rotan 
Kelompok Pahari Palangaka Raya melaksanakan usahanya dengan mengolah bahan baku rotan setengah jadi menjadi produk jadi atau siap pakai seperti kerajinan rotan, tikar, tas, topi, lawung dan berbagai produk lainnya yang dapat disesuaikan dengan keinginan dan pesanan konsumen dengan wilayah pemasaran secara lokal (Kalimantan Tengah).

Tabel 2. Harga Jual Produk UKM Rotan Kelompok Pahari Palangka Raya

\begin{tabular}{|c|c|c|c|}
\hline No & Nama Produk & $\begin{array}{l}\text { Harga Jual } \\
\text { (Rp) }\end{array}$ & Keterangan \\
\hline 1 & $\begin{array}{c}\text { Tas } \\
\text { Tenteng/Wanita }\end{array}$ & $\leq 500.000$ & 1 unit \\
\hline 2 & Tas Ransel Besar & 750.000 & 1 unit \\
\hline 3 & Tas Ransel Kecil & 150.000 & 1 unit \\
\hline 4 & $\begin{array}{l}\text { Tas Selempang } \\
\text { Laki-Laki }\end{array}$ & 300.000 & 1 unit \\
\hline 5 & $\begin{array}{c}\text { Tas Selempang } \\
\text { Wanita }\end{array}$ & 350.000 & 1 unit \\
\hline 6 & Tas Map Polos & 100.000 & 1 unit \\
\hline 7 & Tas Map Motif & 150.000 & 1 unit \\
\hline 8 & $\begin{array}{c}\text { Tas } \\
\text { Tembuleng/Gend } \\
\text { ong }\end{array}$ & 250.000 & 1 unit \\
\hline 9 & $\begin{array}{l}\text { Topi Laki } \\
\text { Laki/Wanita }\end{array}$ & 150.000 & 1 unit \\
\hline 0 & Topi Pet & 100.000 & 1 unit \\
\hline 11 & $\begin{array}{c}\text { Lawung/Laki } \\
\text { Laki }\end{array}$ & 60.000 & 1 unit \\
\hline 12 & Sumping/Wanita & 60.000 & 1 unit \\
\hline 13 & Dompet Lipat & 100.000 & 1 unit \\
\hline 14 & Dompet Klip & 200.000 & 1 unit \\
\hline 15 & Dompet Jenteng & 250.000 & 1 unit \\
\hline 16 & 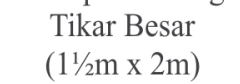 & 1.500 .000 & 1 unit \\
\hline 17 & $\begin{array}{l}\text { Tikar Kecil (1m } \\
\quad \text { x } 2 \mathrm{~m})\end{array}$ & 1.000 .000 & 1 unit \\
\hline 18 & $\begin{array}{l}\text { Tikar Panjang } \\
\text { Batang Garing }\end{array}$ & 750.000 & 1 unit \\
\hline 19 & $\begin{array}{l}\text { Tikar Panjang } \\
\text { Banama Tingang }\end{array}$ & 1.000 .000 & 1 unit \\
\hline
\end{tabular}

\section{Pembahasan}

\section{Manajemen Operasional Desain Produk pada UKM Rotan Kelompok Pahari Palangka Raya}

Berdasarkan hasil penelitian tentang manajemen operasional desain produk pada UKM Rotan Kelompok Pahari Palangka Raya, menerapkan delapan aspek desain produk untuk mencapai manajemen operasional desain produk yang tepat dan terbaik, diantaranya yaitu bentuk, fitur, kinerja, kesesuaian, ketahanan, kehandalan, gaya dan kemudahan perbaikan yang ternyata sesuai dengan teori dari salah satu pendapat ahli. Yang pertama dalam hal bentuk, dapat di diferensiasikan berdasarkan bentuk-ukuran, bentuk atau struktur fisik produk. Pada dasarnya ada bentuk kecil dan besar, perbedaan bentuk tersebut mejadi patokan yang membedakan harga masing-masing produk. Yang kedua dalam hal fitur, dapat melengkapi fungsi dasar dari setiap produk yang ditawarkan dengan penggunaan bahan baku dan kualitas rotan yang sama pada setiap jenis produk, usaha ini menggunakan kapasitas helaian rotan yang lebih banyak agar produk tetap kuat dan bertahan lama. Yang ketiga dalam hal kinerja, disini yang dimaksud adalah kualitas yang menjadi karakteristik utama produk beroperasi, UKM Rotan Kelompok Pahari Palangka Raya menjaga dan meningkatkan kualitas pada saat proses pembuatan yang dilakukan dengan benar-benar teliti agar tidak terjadi kerusakan. Ketika terdapat permintaan yang besar pemilik usaha hanya menambah jumlah persediaan atau membeli alat dan bahan lebih banyak di Yogyakarta dan Bandung. Sedangkan untuk tenaga, hanya menghubungi keluarga yang lain, meskipun beda daerah dan cukup memberi tahu produk apa yang diperlukan tanpa harus dipantau, karena sudah mempunyai keahlian yang sama dalam menjaga dan meningkatkan kualitas produk. Yang keempat dalam hal kesesuaian, hampir semua produk yang diproduksi sesuai dan memenuhi spesifikasi yang dijanjikan ketika sudah sampai ditangan konsumen. Namun pada saat proses pembuatan produk terjadi kecacatan, misalnya ada rotan yang putus atau sobek, maka segera menyambung atau melapisnya menggunakan lem dengan rapi agar tidak kelitan sobek atau putusnya 
dan tetap terlihat sempurna. Yang kelima dalam hal ketahanan, setiap produk yang diproduksi oleh UKM Rotan Kelompok Pahari Palangka Raya dapat bertahan lama jika konsumen menjaga produk dengan baik. Pemilik UKM Rotan Kelompok Pahari Palangka Raya mengatakan bahwa produk rotan bagus terhadap sinar matahari dan tidak bagus terhadap air, tetapi ketika sudah dicat tidak bagus ditaruh dibawah sinar matahari. Yang keenam dalam hal kehandalan, suatu produk memiliki kehandalan yang dapat digunakan dalam jangka waktu yang lama. Bahan baku rotan lebih awet ketika dibuat tikar, karena jarang digunakan. Tidak seperti tas dan dompet yang hampir setiap hari digunakan, sehingga kualitas dan keawetan rotan berkurang. Yang ketujuh dalam hal gaya, produk hasil UKM Rotan Kelompok Pahari Palangka Raya memiliki beberapa motif atau gaya seperti ihing, batang garing, bejakah kelelawit dan banyak motif lainnya ada 65 motif. Penciptaan motif atau gaya termotivasi dari alam dan insting atau kreasi sendiri, bahkan bisa mengerjakan motif atau gaya berdasarkan permintaan konsumen. Untuk pewarna UKM Rotan Kelompok Pahari Palangka Raya melakukan tahap pewarnaan pada saat tahap finishing, cat kayu mengkilap yang memberikan perlindungan pada produk rotan dan tidak memiliki bau menyengat ialah cat Biovarnish. Yang kedelapan dalam hal kemudahan perbaikan, pemilik UKM Rotan Kelompok Pahari Palangka Raya mengatakan bahwa usaha ini bisa memperbaiki kembali produk yang rusak, ketika produk sudah ditangan konsumen dan mengalami kerusakan masih bisa diperbaiki, tetapi ada tambahan biaya. Karena ada konsumen yang meminta untuk dipermak lebih baik atau menambah bahan baru.

Manajemen Operasional Rantai Pasokan

\section{pada UKM Rotan Kelompok Pahari Palangka Raya}

Berdasarkan hasil wawancara mengenai manajemen operasional rantai pasokan yang diterapkan UKM Rotan Kelompok Pahari Palangka Raya ialah strategi rantai pasokan banyak pemasok yang didasarkan beberapa faktor penentu strategi rantai pasokan yaitu hubungan pemasok dengan perusahaan, pengiriman, kualitas, waktu, fleksibibilitas, dan biaya. Yang pertama dalam hal hubungan pemasok dengan perusahan, UKM Rotan Kelompok Pahari Palangka Raya mendapat pasokan bahan baku dari Barito Selatan sebanyak 4-5 pemasok dengan mempertimbangkan dari segi biaya, jarak dan kualitas tetapi lebih mengutamakan pemasok dari keluarga dengan tujuan membantu perekonomian keluarga. Yang kedua dalam hal pengiriman, pemasok selalu mengirim rotan tepat waktu ketika pemilik usaha UKM Rotan Kelompok Pahari Palangka Raya sudah mentransfer uang. Bahan baku yang dikirim secara berkala bisa dua sampai tiga kali pengiriman. Untuk mensiasati kekurangan rotan dari pemasok usaha ini menghubungi keluarga jauh-jauh hari, tapi misalkan ditempat keluarga masih kekurangan barang pasokan atau tidak mencukupi permintaan, maka keluarga langsung mencarikan pemasok yang lain untuk memenuhinya. Yang ketiga dalam hal kualitas, bahan baku dengan kualitas baik dapat mempengaruhi hasil akhir produk yang mudah dalam pengerjaan dan awet dalam pemakaian produk tersebut, pemilik UKM Rotan Kelompok Pahari Palangka Raya mengatakan bahwa dalam memilih pemasok lebih mengutamakan keluarga dan sudah tidak meragukan lagi dengan kualitas bahan baku yang dimiliki pemasok tersebut. Yang keempat dalam hal waktu, pengiriman bahan baku yang selalu datang sesuai dengan waktu yang ditentukan oleh keinginan usaha ini merupakan salah satu faktor penting dalam 
memilih pemasok. Pemilik UKM Rotan Kelompok Pahari Palangka Raya mengatakan bahwa bahan baku dikirim sesuai permintaan saja tidak setiap bulan dan untuk cadangan bahan baku selalu ada, karena pihak UKM Rotan Kelompok Pahari Palangka Raya selalu memproduksi setiap hari. Yang kelima dalam hal fleksibilitas disini yang dimaksud adalah kemampuan UKM Rotan Kelompok Pahari Palangka Raya untuk tetap bisa menyesuaikan secara mudah dan cepat apabila terjadi permintaan produk yang besar, yaitu dengan menghubungi pemasok keluarga dari Barito Selatan, tapi misalkan ditempat keluarga masih kekurangan barang pasokan atau tidak mencukupi permintaan, maka keluarga langsung mencarikan pemasok yang lain untuk memenuhinya. Yang keenam dalam hal biaya, penetapan harga bahan baku oleh pemasok tidak menjadi masalah bagi UKM Rotan Kelompok Pahari Palangka Raya tetapi lebih mengutamakan membeli dengan keluarga untuk membantu perekonomiannya. Biaya pengiriman bahan baku rotan ditanggung oleh pihak UKM Rotan Kelompok Pahari Palangka Raya, dan sistem pembayaran kepada pemasok dilakukan secara lunas melalui transfer di bank. Berdasarkan hasil data wawancara, UKM Rotan Kelompok Pahari Palangka Raya memiliki faktor pendorong dan faktor penghambat bagi kemajuan usahanya. Adapun faktor pendorong bagi kemajuan UKM Rotan Kelompok Pahari Palangka Raya yaitu memiliki izin usaha, menekankan pada kualitas dan mutu produk, harga terjangkau, dari segi motif, ukuran dan desain dapat disesuaikan dengan keinginan konsumen, serta ketepatan waktu pengerjaan. Sedangkan faktor penghambat bagi kemajuan usaha ini yaitu timbulnya para pesaing, adanya perbedaan harga dengan produk lain, serta produk yang ditawarkan mempunyai kesamaan dengan produk lain.

\section{PENUTUP}

Simpulan

Berdasarkan hasil penelitian dan pembahasan, dapat peneliti simpulkan sebagai berikut: 1) Manajemen operasional desain produk yang tepat untuk meningkatkan hasil penjualan produk UKM Rotan Kelompok Pahari Palangka Raya yaitu dengan menerapkan delapan aspek desain produk (bentuk, fitur, kinerja, kesesuaian, ketahanan, kehandalan, gaya, dan kemudahan perbaikan) dengan prioritas pada produk dan harga yang dipasarkan. 2) Manajemen operasional rantai pasokan yang tepat untuk meningkatkan hasil produksi UKM Rotan Kelompok Pahari Palangka Raya yaitu dengan menerapkan strategi rantai pasokan banyak pemasok dengan prioritas keluarga, biaya, kualitas dan jarak. 3) Faktor pendorong bagi kemajuan UKM Rotan Kelompok Pahari Palangka Raya yaitu memiliki izin usaha, menekankan pada kualitas dan mutu produk, harga terjangkau, dari segi motif, ukuran dan desain dapat disesuaikan dengan keinginan konsumen, serta ketepatan waktu pengerjaan. Sedangkan faktor penghambat bagi kemajuan usaha ini yaitu timbulnya para pesaing, adanya perbedaan harga dengan produk lain, serta produk yang ditawarkan mempunyai kesamaan dengan produk lain.

\section{Saran}

Berdasarkan kesimpulan tersebut, maka saran dari peneliti adalah sebagai berikut: 1) Diharapkan untuk meningkatkan prioritas terhadap produk dan harga yang dipasarkan yaitu dengan mampu memproduksi produk lebih banyak lagi agar dapat memenuhi permintaan pasar baik ditingkat nasional maupun internasional dengan harga yang mampu bersaing dari para pesaing lainnya agar produk UKM Rotan Kelompok Pahari Palangka Raya tetap berada dipasaran. 2) Diharapkan untuk pemilihan pemasok rotan tidak hanya memprioritaskan 
keluarga saja, tetapi dari masyarakat umumnya. Agar pemilik usaha lebih memperbanyak pemasok baik dari dalam maupun luar Kalimantan Tengah dan terhindar dari kesulitan mencari bahan baku rotan, namun tetap mempertimbangkan dari segi biaya, kualitas, dan jarak. 3) Dilihat dari faktor penghambat bagi kemajuan usaha ini, salah satunya adalah produk yang ditawarkan sama dengan produk lain, dalam hal ini diharapkan agar pemilik usaha lebih memperbanyak kreasi atau motif lagi agar masalah ini dapat teratasi dan konsumen tetap memilih UKM Rotan Kelompok Pahari Palangka Raya untuk berbelanja kerajinan rotan.

\section{DAFTAR PUSTAKA}

Adisaputo, Gunawan. (2014). Manajemen Pemasaran Analisis Untuk Perancangan Strategi Pemasaran. Cetakan ke-2. Yogyakarta: UPP STIM YKPN

Assauri, Sofjan. (2016). Manajemen Operasi Produksi Pencapaian Sasaran Organisasi Berkesinambungan. Edisi 3, Cetakan ke-2. Jakarta: Rajawali Pers.

Dudung, Agus. (2012). Merancang Produk. Bandung: PT Remaja Rosdakarya.

Haizer, Jay dan Render, Barry. (2016). Manajemen Operasi: Manajemen Keberlangsungan dan Rantai Pasokan. Edisi ke-11. Jakarta: Salemba Empat.

Haming, Murdifin dan Nurnajamuddin, Mahfud. (2011). Manajemen Produksi Modern Operasi Manufaktur dan Jasa. Edisi ke-2. Buku 1. Jakarta: PT Bumi Aksara.

Jacobs, Robert F dan Chase Richard B. (2015). Manajemen Operasi dan Rantai Pasokan. Edisi ke-14. Buku 1. Jakarta: Salemba Empat.

Kotler, Philip. (2008). Manajemen Pemasaran. Jakarta: Erlangga.
Kotler, Philip dan Keller, Kevin L. (2009). Manajemen Pemasaran. Edisi ke-13. Jilid 1 dan 2. Jakarta: Erlangga.

Ma'arif, M. Syamsul dan Tanjung, Hendri. (2003). Manajemen Operasi. Jakarta: PT Grasindo.

Moleong, Lexy J. (1990). Metodologi Penelitian Kualitatif. Bandung: PT Remaja Rosdakarya.

Sugiyono. (2013). Metode Penelitian Pendidikan Pendekatan Kuantitatif, Kualitatif, dan R\&D. Bandung: Alfabeta.

Sugiyono. (2015). Metode Penelitian Pendidikan Pendekatan Kuantitatif, Kualitatif, dan R\&D. Bandung: Alfabeta.

Tim Penyusun. (2017). Pedoman Penulisan Skripsi. Palangka Raya: Universitas Palangka Raya.

Tjiptono, Fandy. (2008). Strategi Pemasaran. Yogyakarta:ANDI.

Alfianto, Eko Agus.(2014). Pengaruh Desain Produk Dan Layanan Purna Jual Terhadap Keputusan Konsumen Membeli Sepeda Motor Yamaha Merek New V-Ixion FI (Full Injection). Diunduh pada tanggal 9 Januari 2019, dari https://docplayer.info/221755Pengaruh-desain-produk-dan-layananpurna-jual-terhadap-keputusankonsumen-membeli-sepeda-motoryamaha-merek-new-v-ixion-fi. html

Riskiya, Eka. (2012). Analisis Strategi Desain Produk Dalam Meningkatkan Volume Penjualan Pada Produk Mebel Antik CV. Gardu Antique Indah Situbondo. Diunduh pada tanggal 9 Januari 2019, dari http://etheses.uinmalang.ac.id/2023/2/08510141_Indon esia.pdf 
Renata, Rio Pascal. (2018). Implementasi Supply Chain Management (SCM) Pada UKM Emping Mlinjo Di Sukoharjo. Diunduh pada tanggal 9 Januari 2019, dari http://eprints. ums.ac.id/ 60958/12/NASKAH\% 20PUBLIKASI_Rio_libraryums.pdf

Oktaviani, Olivia. (2015). Pengaruh Desain Produk Terhadap Keputusan Pembelian Konsumen (Studi Kasus Pada Distro Flashy Bandung). Diunduh pada tanggal 20 Desember 2018, dari http://repository.unisba. ac.id/handle/123456789/128

Wicaksono, Satria Adhi. (2015). Pengaruh Merek dan Desain Terhadap Minat Beli Konsumen. Diunduh pada tanggal 20 Desember 2018, dari http:1ib. unnes.ac.id/21460

https://www.google.com/url? sa $=$ t $\&$ source $=$ web\&rct=j\&url=https://www.bi.go.id/i d/tentang-bi/uu-bi/Documents/ UU20Tahun2008UMKM.pdf\&ved=2a hUKEwjSgNiV5oPgAhVLQI8KHW $\underline{\text { KxCd4QFjAAegQIBRAB\&usg=AOv }}$ Vaw19LC8HiAxurhWX8bbD7nTR. Di unduh pada tanggal 20 Desember 2018

https://www.google.com/url? sa=t\&source= web\&rct=j\&url=http://eprints.umpo.ac
$. \mathrm{id} / 4123 / 3 / 3 . \% 2520 \mathrm{BAB} \% 2520 \mathrm{II} . \mathrm{pdf}$ \&ved=2ahUKEwjjsJWokf fAhWwgU sFHVV-DfEQFjAAegQIAhAB\&usg $=$ AOvVaw3EOeinmubDmvoZliQK67 yZ\&cshid $=1548082798926$. Di unduh pada tanggal 15 Januari 2019

https://www.google.com/url? sa=t\&source= web\& $\mathrm{rct}=\mathrm{j} \&$ url=http://repository.unpa s.ac.id/28824/6/10.\%2520BAB $\% 2520$ II.pdf\&ved=2ahUKEwiC4Mrmmf fA hVIi3AKHb2tBuAQFjABegQIAhAB \&usg=AOvVaw0k8egaEOy91VOPEdhOrxW. Di unduh pada tanggal 20 Desember 2018

https://www.google.com/url? sa=t\&source $=$ web\&rct=j\&url=https://repository.wid yatama.ac.id/xmlui/bitstream/handle/1 23456789/3621/Bab\%25202.pdf\%3Fs equence $\% 3 \mathrm{D} 7 \&$ ved $=2$ ahUKEwjyz6y Xm fAhWMto8KHTZrD08QFjAAe gQIBRAB\&usg=AOvVaw3P1nAB2c YbW6j 5OwJ5jAH. Di unduh pada tanggal 20 Desember 2018

https://www.google.com/url?sa=t\&source $=$ web\&rct $=$ j\&url=https://yosnex.files.w ordpress.com/2016/09/11_skripsiscm-rantai-pasok.pdf\&ved= 2ahUKEwiY9Ibaov fAhUQaI8KHW 4MB2IQFjAAegQIAxAB\&usg=AOv Vaw1xnGbuiz0YAFt2ZxdCGdSi. Di unduh pada tanggal 27 Desember 2018 